\title{
REALNI POTENCIAL ZA LOKALNO OSKRBO S HRANO V SLOVENIJI
}

\author{
mag. Anton Perpar, dr. Andrej Udovč \\ Oddelek za agronomijo, Biotehniška fakulteta Univerze v Ljubljani \\ Jamnikarjeva I0I, SI-I000 Ljubljana \\ e-mail: anton.perpar@bf.uni-lj.si; andrej.udovc@bf.uni-lj.si
}

\section{Pregledni znanstveni članek}

COBISS 1.02

\section{Izvleček}

V Sloveniji se je stopnja samooskrbe s prehranskimi proizvodi v zadnjih letih zmanjšala, za nekatere proizvode celo pod polovico. V prispevku so podane kvalitativne ocene možnosti za izboljšanje trenutne stopnje samooskrbe. Ocene temeljijo na primerjalni analizi proizvodnih potencialov kmetijskih zemljišč, projekciji razvojnih trendov na področju kmetijstva in rabe kmetijskih zemljišč ter trendov v potrošnji hrane. Dodana je tudi analiza primerov dobrih praks zagotavljanja lokalne oskrbe s hrano ter rezultati modela MOLAND, ki simulira prihodnje rabe kmetijskih zemljišč glede na možne globalne razvojne scenarije.

Ključne besede: lokalna oskrba, hrana, kmetijska pridelava, samooskrba, Slovenija

\section{EXISTING POTENTIAL FOR LOCAL FOOD SUPPLY IN SLOVENIA}

\begin{abstract}
The degree of self-sufficiency with food products in Slovenia has decreased in the last years, for some products even bellow one half. In the article the qualitative analyses of possibilities for self-sufficiency improvement are presented. They are based on comparative analysis of production potentials of agricultural land, projection of the development trends in agriculture and agricultural land use and trends in food consumption. An analysis of good practices with local food supply and results of MOLAND model (simulating possible future agricultural land use on the basis of different possible future development scenarios) are added as well.
\end{abstract}

Key words: local supply, food, agricultural production, self-sufficiency, Slovenia 


\section{UVOD}

V pričakovanih razmerah nestabilne oskrbe s hrano na globalni ravni, pa tudi zaradi spoznanj o negativnih okoljskih učinkih velikih (tudi medcelinskih) transportov hrane, postaja vprašanje lokalne in regionalne samooskrbe s hrano ponovno pomembno, prehranska varnost ter lastna proizvodnja hrane pa postajata ponovno strateški politični vprašanji tudi v Sloveniji. Slovenija z domačo pridelavo ne pokriva svojih potreb po kmetijsko-živilskih proizvodih, stopnja samooskrbe pa je za živalske proizvode precej višja kot za rastlinske proizvode.

Pridelava in prireja rastlinskih in živalskih prehranskih proizvodov je osnovna naloga kmetijskega sektorja, kjer se v zadnjih nekaj letih dogajajo razmeroma precejšnje spremembe. V Sloveniji se s kmetijsko pridelavo in prirejo ukvarja okrog 77.000 kmetijskih gospodarstev, njihovo število pa z leti upada. V strukturi rabe kmetijskih zemljišč zavzemajo največji delež trajni travniki in pašniki, njihova površina se v zadnjih letih bistveno ne spreminja. Obseg živinoreje v zadnjih letih upada, saj se zmanjšuje tako število kmetijskih gospodarstev, ki redijo živino, kot tudi število živine.

Naravni pogoji za kmetovanje in zgodovinski razvoj agrarne strukture v Sloveniji ne omogočajo visoke produktivnosti v kmetijstvu. Velik delež zemljišč je na območju s težjimi naravnimi razmerami za pridelavo, posestva so razmeroma majhna in močno razdrobljena, njihova stopnja specializacije je nizka, velikostna struktura kmetijskih gospodarstev pa s stališča doseganja pogojev za visoke ekonomske rezultate dokaj neugodna. V zadnjem času sicer prihaja do nekaterih strukturnih sprememb. Število kmetijskih gospodarstev se znižuje, zato se površina kmetijske zemlje v uporabi na kmetijo nekoliko povečuje, s tem pa se povečuje tudi povprečna velikost kmetijskih gospodarstev, a še vedno manj od želenega. Rezultati kažejo, da se je po letu 2006 ta proces ponovno ustavil.

Drugi razlog, ki je z vidika samooskrbe hrane v Sloveniji zaskrbljujoč, je pozidavanje in spreminjanje namembnosti kmetijskih zemljišč z najboljšim pridelovalnim potencialom. Obseg teh zemljišč je v Sloveniji že po naravi zelo omejen, Slovenija pa je glede zagotavljanja prehranske varnosti na podlagi lastnih kmetijskih zemljišč povsem na koncu lestvice držav članic Evropske unije.

\section{STANJE PRIDELOVALNIH VIROV V SLOVENIJI}

V strukturi rabe tal v Sloveniji pretežni del ozemlja pokrivajo gozdovi (59,8 \%), njihova površina pa se je doslej še povečevala. Kmetijska zemljišča najdemo na 32 \% celotnega državnega ozemlja, preostalih 8,2 \% pa predstavljajo ostala zemljišča (pozidano, močvirja ipd; PRP 2007-2013 2010, 17). V strukturi rabe kmetijskih zemljišč po evidenci o dejanski rabi kmetijskih zemljišč in gozdov največji delež zavzemajo trajni travniki in pašniki $(54,6$ \%), sledijo njive (30,3 \%) ter trajni nasadi $(8,4 \%)$. Slabih 7 \% predstavljajo ostala kmetijska zemljišča, na katerih je bilo gospodarjenje zaradi naravnih, ekonomskih ali socialnih razlogov opuščeno. Kar 85 \% nacionalnega ozemlja, oziroma 72,5 \% kmetijskih zemljišč, se nahaja v območjih z omejenimi možnostmi za kmetovanje (OMD). 
Obseg kmetijske proizvodnje v Sloveniji po letu 2000 močno niha, pretežno kot posledica naravnih razmer, ki so bile v zadnjih letih zelo spremenljive. V letu 2008 je bil fizični obseg kmetijske proizvodnje za 0,8 \% manjši kot predhodno leto. Zmanjšala se je rastlinska pridelava $(-1,6 \%)$, medtem ko v živinoreji na agregatni ravni ni prišlo do večjih sprememb v obsegu proizvodnje (Poročilo o stanju kmetijstva... 2009, 17).

Preglednica 1: Izbrani kazalci stanja v slovenskem kmetijstvu v obdobju med 2000 in 2008

Table 1: Selected indicators of the situation in Slovenian agriculture betwen 2000 and 2008

\begin{tabular}{|l|r|r|r|r|r|r|r|r|r|}
\hline & $\mathbf{2 0 0 0}$ & $\mathbf{2 0 0 1}$ & $\mathbf{2 0 0 2}$ & $\mathbf{2 0 0 3}$ & $\mathbf{2 0 0 4}$ & $\mathbf{2 0 0 5}$ & $\mathbf{2 0 0 6}$ & $\mathbf{2 0 0 7}$ & $\mathbf{2 0 0 8}$ \\
\hline Kmetijska zemlja v uporabi (000 ha KZU) & 509,0 & 509,6 & 505,5 & 509,7 & 490,5 & 508,8 & 490,3 & 498,6 & 492,4 \\
\hline Stevilo kmetijskih gospodarstev (000) & 86,5 & & & 77,1 & & 77,2 & & 75,3 & \\
\hline KZU/kmetijsko gospodarstvo (ha) & 5,6 & & & 6,3 & & 6,3 & & 6,5 & \\
\hline Delež kmetijstva v BDP (BDV/BDP) (\%) & 2,0 & 1,7 & 2,1 & 1,5 & 1,8 & 1,7 & 1,5 & 1,2 & 1,1 \\
\hline Delež kmetijstva v zaposlenosti (\%) & 11,5 & 11,8 & 11,5 & 10,4 & 9,8 & 9,8 & 9,5 & 8,7 & 8,4 \\
\hline $\begin{array}{l}\text { Delež agroživilskih proizvodov v } \\
\text { skupnem izvozu blaga (\%) }\end{array}$ & 3,8 & 3,7 & 3,7 & 3,6 & 2,8 & 2,9 & 3,1 & 3,3 & 3,9 \\
\hline $\begin{array}{l}\text { Delež agroživilskih proizvodov v } \\
\text { skupnem uvozu blaga (\%) }\end{array}$ & 6,4 & 6,6 & 6,6 & 6,3 & 6,3 & 6,5 & 6,4 & 6,8 & 7,3 \\
\hline $\begin{array}{l}\text { Rast cen hrane in pijač pri porabnikih } \\
\text { (\%, realno)** }\end{array}$ & $-3,1$ & 0,7 & 0,0 & $-0,9$ & $-3,0$ & $-3,2$ & $-0,2$ & 4,0 & 4,2 \\
\hline $\begin{array}{l}\text { Delež izdatkov za hrano, pijačo in tobak } \\
\text { v končni porabi gospodinjstev (\%) }\end{array}$ & 22,1 & 22,1 & 21,5 & 21,4 & 20,4 & 19,8 & 19,5 & 19,3 & 19,3 \\
\hline
\end{tabular}

* po podatkih strukturnih popisov kmetijstva v letih 2000, 2003, 2005 in 2007

** sprememba glede na predhodno leto

Vir/Source: SURS

Slika 1: Indeksi kmetijske proizvodnje v Sloveniji 1996-2008

Figure 1: Indexes of agricultural production in Slovenia 1996-2008

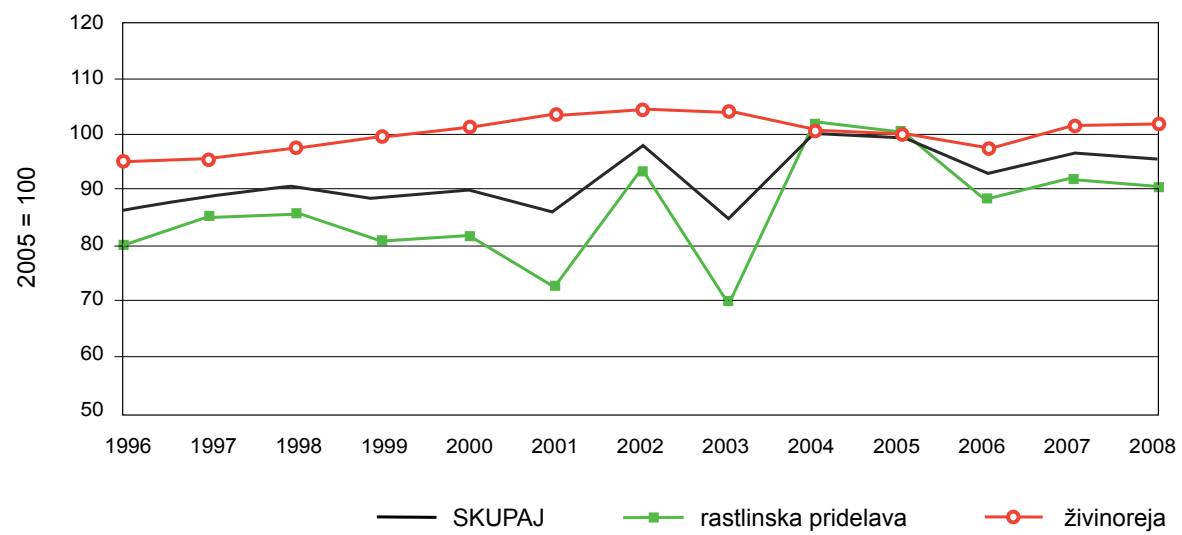

Vira/Sources: SURS, EUROSTAT 
Več kot polovica njiv je namenjena pridelavi žita, zlasti koruze za zrnje in pšenice, več kot četrtina pa pridelavi zelene krme, kjer prevladujeta silažna koruza ter trave in travno-deteljne mešanice. Od leta 2005 se je setvena struktura njiv precej spremenila. Povečal se je delež pšenice in drugih strnih žit, oljnic ter krmnih koševin, zmanjšal pa delež silažne koruze in krompirja. Rastlinska pridelava je k bruto vrednosti kmetijstva v letu 2008 prispevala 48 \% (leta 200753 \%) (Poročilo o stanju kmetijstva... 2009, 18).

Slika 2: Setvena struktura njiv za leti 2005 in 2008

Figure 2: Seed structure of arable land for 2005 and 2008

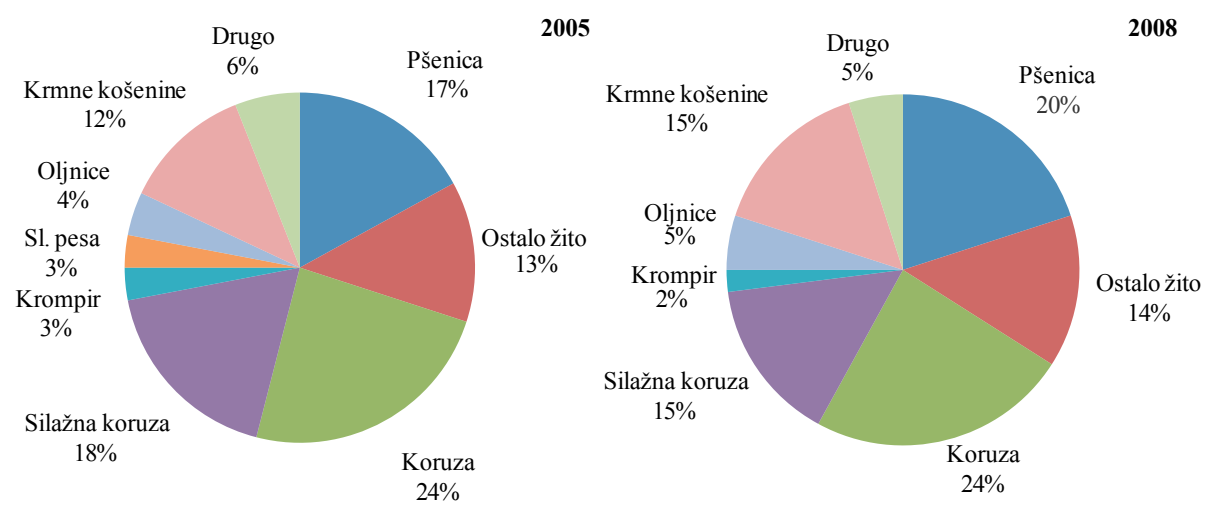

Površina kmetijske zemlje v uporabi kmetijskih gospodarstev v zadnjih letih obsega okrog 500.000 hektarov (Poročilo o stanju kmetijstva... 2009, 17). Ob tem je opazen rahel trend povečevanja površine njiv, medtem ko se površine trajnih nasadov zmanjšujejo, predvsem zaradi opuščanja rabe kmečkih sadovnjakov. V letu 2008 se je površina kmetijske zemlje $\mathrm{v}$ rabi v primerjavi z letom prej zmanjšala za dober odstotek, kar je v celoti rezultat manjše površine travinja $(-3,8 \%)$.

Preglednica 2: Kmetijska zemlja v uporabi na kmetijskih gospodarstvih v Sloveniji 2000-2008 Table 2: Agricultural land in use on agricultural holdings in Slovenia 2000-2008

\begin{tabular}{|l|r|r|r|r|r|r|r|r|r|}
\hline 000 ha & $\mathbf{2 0 0 0}$ & $\mathbf{2 0 0 1}$ & $\mathbf{2 0 0 2}$ & $\mathbf{2 0 0 3}$ & $\mathbf{2 0 0 4}$ & $\mathbf{2 0 0 5}$ & $\mathbf{2 0 0 6}$ & $\mathbf{2 0 0 7}$ & $\mathbf{2 0 0 8}$ \\
\hline Njive in vrtovi & 170,8 & 172,7 & 168,4 & 172,8 & 175,1 & 176,3 & 177,8 & 175,1 & 180,3 \\
\hline Trajni nasadi & 29,9 & 29,9 & 29,9 & 28,6 & 28,6 & 27,5 & 27,5 & 26,1 & 26,1 \\
\hline Travniki in pašniki & 308,2 & 307,0 & 307,2 & 308,3 & 286,8 & 304,9 & 285,0 & 297,3 & 286,0 \\
\hline $\begin{array}{l}\text { Kmetijska zemlja } \\
\text { v uporabi, skupaj }\end{array}$ & $\mathbf{5 0 9 , 0}$ & $\mathbf{5 0 9 , 6}$ & $\mathbf{5 0 5 , 5}$ & $\mathbf{5 0 9 , 7}$ & $\mathbf{4 9 0 , 5}$ & $\mathbf{5 0 8 , 8}$ & $\mathbf{4 9 0 , 3}$ & $\mathbf{4 9 8 , 6}$ & $\mathbf{4 9 2 , 4}$ \\
\hline
\end{tabular}

Vir/Source: SURS 
V zadnjih letih raste tudi število kmetij, ki se ukvarjajo z ekološko pridelavo hrane. V letu 2008 je bilo takih kmetij 2046 ali 2,7 \% vseh kmetij, ekološke proizvode pa so pridelovale na 29.836 ha ali 4,8 \% vseh kmetijskih zemljišč (medmrežje 1). Razmere na trgu kažejo, da je ponudba ekološko pridelane hrane v Sloveniji še vedno manjša od povpraševanja, zato jo tudi uvažamo. Možnosti tovrstne pridelave torej še niso izkoriščene.

Obseg površin za pridelavo hrane se nam zaradi sprememb rabe tal iz kmetijske v nekmetijsko rabo stalno zmanjšuje, še posebej intenzivno v zadnjem obdobju. Slovenija se po obsegu kmetijskih obdelovalnih površin (njiv in vrtov) glede na celotno površino države uvršča na 25. mestu v EU. Te obsegajo le 8,8 \% države, evropsko povprečje pa znaša kar trikrat več, to je $25,9 \%$. Problematika zbuja skrb toliko bolj zaradi negativnega trenda, saj smo med letoma 2002 in 2007 zaradi pozidave in urbanizacije v povprečju izgubili 7 hektarjev kmetijskih zemljišč na dan (Pintar in sod. 2010, 1), velike pa so tudi zahteve za spremembo namembnosti kmetijskih zemljišč v zazidalna $\mathrm{v}$ prostorskih planih, ki jih trenutno pripravljajo slovenske občine. Dejstvo, da imamo le okrog $880 \mathrm{~m}^{2}$ njivskih površin na prebivalca, za preživetje na podlagi lastne pridelave pa bi po grobi oceni potrebovali vsaj $2000 \mathrm{~m}^{2}$, od nas nujno zahteva racionalen odnos do kmetijskih zemljišč in trajnosten razvoj v prostoru. Po drugi strani se nam del kmetijskih zemljišč še zarašča in s tem zmanjšuje njihova vloga pridelovanja hrane.

V nadaljevanju podajamo kvalitativno oceno možnosti Slovenije za izboljšanje trenutne stopnje samooskrbe. Temelji na primerjalni analizi proizvodnih potencialov kmetijskih zemljišč v Sloveniji, projekciji razvojnih trendov na področju kmetijstva in rabe kmetijskih zemljišč ter trendov $\mathrm{v}$ potrošnji hrane. $\mathrm{V}$ ta namen smo uporabili tudi modelne rezultate modela MOLAND, v okviru katerega so bili izdelani razvojni scenariji prihodnje rabe kmetijskih zemljišč glede na pričakovane globalne razvojne trende. Drugi metodološki pristop za izdelavo pričujoče ocene je bila analiza obstoječih dobrih praks na področju bolj aktivnega sodelovanja med proizvajalci in potrošniki, $\mathrm{z}$ namenom skrajševanja tržnih poti in zagotavljanja oskrbe z lokalno pridelano hrano.

\section{STANJE NA PODROČJU SAMOOSKRBE}

Koncept 'prehranske varnosti' vključuje:

- sposobnost sistema zagotavljanja hrane, da je učinkovit tudi v izrednih in kriznih razmerah (npr. poplave, teroristični napadi ali motnje pri oskrbi z energenti);

- stopnjo potencialne samooskrbe (v veliki meri vezana na obstoječo stopnjo in potencialno možnost lokalne samooskrbe s hrano);

- sledljivost proizvodnje in v povezavi s tem zagotovilo, da je pridelano neškodljivo glede na obstoječe in bodoče standarde kakovosti.

Prehranska varnost je dejansko koncept, ki bi moral biti vključen v celotno prehransko verigo, od proizvajalcev preko živilske industrije do trgovcev. Strategije zagotavljanja prehranske varnosti posameznega območja ali države običajno vsebujejo dve razsežnosti. Prva je vezana na zagotavljanje trajnostne samooskrbe prek celotne prehranske verige, vključno 
s pospeševanjem porabe lokalnih proizvodov. Druga razsežnost pa obravnava področja, na katera ima lokalna samooskrba neposreden ali posreden vpliv, in sicer: zdravje, okolje, gospodarstvo, družbo in kulturo ter varnost (London food strategy 2006, 33).

Slovenija z domačo pridelavo ne pokriva svojih potreb po kmetijsko-živilskih proizvodih. Stopnja samooskrbe v Sloveniji je za živalske proizvode precej višja kot za rastlinske proizvode. Stalni presežki se pojavljajo le pri hmelju, ki je skoraj v celoti namenjen svetovnemu trgu, mleku (stopnja samooskrbe med 113 in $120 \%$ ), perutninskem mesu (stopnja samooskrbe med 110 in $115 \%$ ) in svežih jabolkih (neto izvoz med 10.000 in 15.000 ton letno). Pri govejem mesu je po letu 2005 bilanca dokaj izravnana (stopnja samooskrbe med 98 in $103 \%$ ). Največji primanjkljaj beležimo pri sladkorju, ki ga sami ne proizvajamo več, ter rastlinskem olju, velik je tudi pri zelenjavi (stopnja samooskrbe pod $40 \%$ ), žitu (stopnja samooskrbe okrog $50 \%$ pri pšenici in okrog $60 \%$ pri žitu skupaj), svežem sadju (neto uvoz okoli 100.000 ton letno), krompirju (stopnja samooskrbe med 60 in $70 \%$ ) in svinjskem mesu (stopnja samooskrbe pod $70 \%$ ). Primanjkljaj se pojavlja tudi pri medu (stopnja samooskrbe okrog $80 \%$ ) in jajcih (stopnja samooskrbe okrog $95 \%$ ). Pri mesu drobnice sta prireja in poraba dokaj izravnani. Pri vinu se izvozno-uvozni status spreminja, pri čemer je Slovenija tradicionalno neto izvoznica kakovostnega vina in neto uvoznico namiznega vina (Osnutek resolucije o strateških usmeritvah razvoja slovenskega kmetijstva in živilstva 2010, 4-5).

Slika 3: Stopnja samooskrbe po posameznih kmetijskih in živilskih proizvodih v letu 2008 Figure 3: Self-sufficiency rate for agricultural and food products in 2008

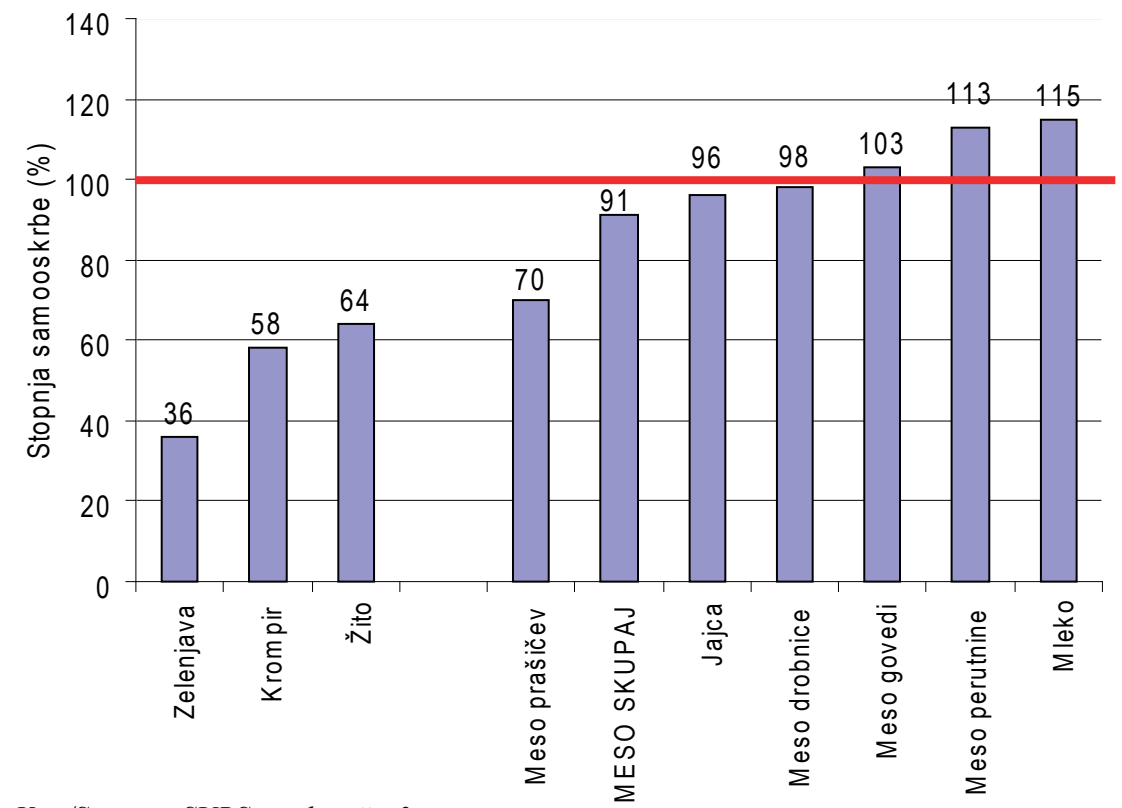

Vira/Sources: SURS, medmrě̌je 3 
V zadnjem obdobju so se stopnje samooskrbe povečale le pri krmnem strnem žitu in mesu govedi (Poročilo o stanju kmetijstva... 2009, 18). Primanjkljaj se je povečal pri tradicionalnih neto uvoznih proizvodih, kot so vrtnine in prašičje meso, stopnja samooskrbe pa se je zmanjšala tudi pri pšenici, krompirju, jajcih in medu. Slovenija v splošnem ostaja neto uvoznica kmetijsko-živilskih proizvodov, njen trgovinski primanjkljaj pa se je po vstopu v Evropsko unijo še povečal. K temu so dodatno pripomogli odpiranje domačega trga, zaprtje nekaterih obratov (npr. Tovarna sladkorja v Ormožu) ter nove distribucijske in tržne strukture.

Slika 4: Saldo menjave kmetijskih in živilskih proizvodov s tujino 2000-2009

Figure 4: Exchange balance of agricultural and food products with foreign countries 2000-2009

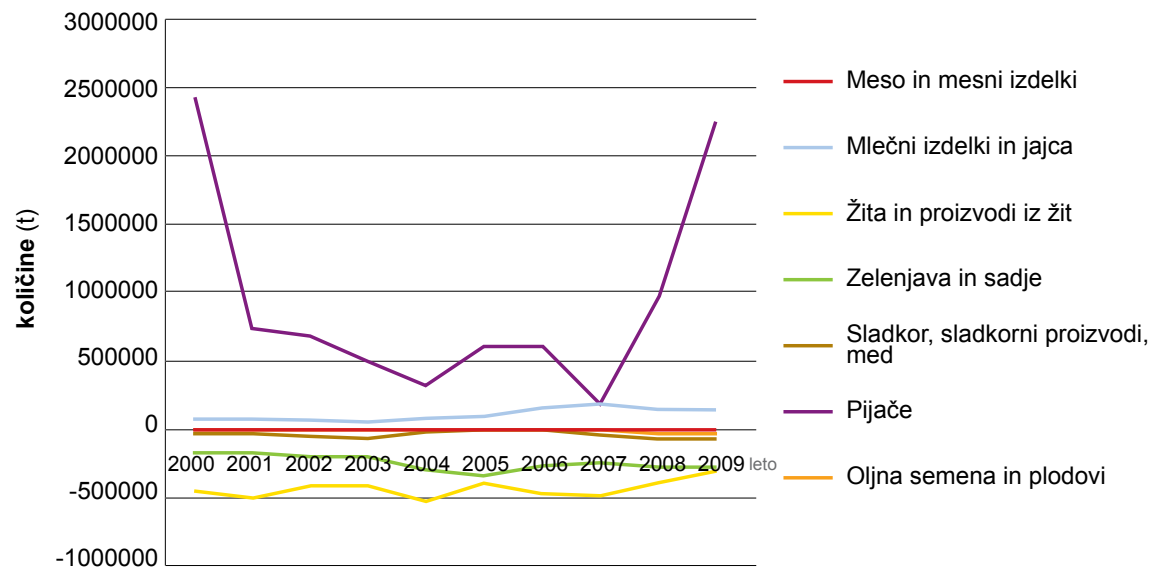

Vira/Sources: SURS, medmrežje 3

Na drugi strani poraba osnovnih kmetijsko-živilskih proizvodov med leti nekoliko niha. Trend rasti porabe na prebivalca je opazen pri zelenjavi, perutninskem mesu, mesu drobnice ter mlečnih izdelkih, pri govejem mesu in vinu pa se je poraba v primerjavi z obdobjem pred vstopom v Evropsko unijo nekoliko zmanjšala. Vzorci porabe v glavnem sledijo vzorcem, značilnim za evropske države. Slovenska gospodinjstva so v letu 2008 namenila za hrano, pijačo in tobačne izdelke okrog $19 \%$ vseh izdatkov. Ta delež se zmanjšuje, vendar ostaja večji od povprečja EU-27 (16\%).

\section{MOGOČI PRIHODNJI RAZVOJNI SCENARIJI IN NJIHOV VPLIV NA PRIDELAVO HRANE}

Kaj pomenijo različni scenariji mogočega prihodnjega razvoja na globalni ravni tudi za pridelavo hrane in kmetijska zemljišča, so poskušali simulirati raziskovalci v evropskem 
raziskovalnem projekt PLUREL ${ }^{1}$. Možni prihodnji scenariji so bili povzeti po Medvladnem odboru za podnebne spremembe (IPCC) in med njimi imata največji vpliv na povečan interes za samooskrbo s hrano dva, in sicer takoimenovani 'Peak oil' ter 'Water World' scenarij (Perpar in sod. 2010, 4-10). V primeru prvega rast cen energentov povzroči povečanje energetskih in transportnih stroškov ter posledično vodi k spremembam v mobilnosti in trgovinskih tokovih. V tem primeru se predvideva povečan interes za kmetovanje in kmetijsko rabo razpoložljivih površin, velika prizadevanja za zmanjšanje negativnih vplivov na okolje, lokalizacijo pridelave in potrošnje. V primeru 'Water World' scenarija pa imajo pomemben vpliv podnebne spremembe, ki po eni strani povzročajo dvig gladine morja, po drugi strani pa tudi več ekstremnih vremenskih pojavov, kot so neurja, poplave in suše. Tudi takšen možen razvoj v prihodnosti zahteva večjo samooskrbo s hrano ter aktivno rabo kmetijskih zemljišč za pridelavo hrane. Za Mestno občino Koper, ki je študija primera v projektu, so bili scenariji preizkušeni v modelu MOLAND, rezultati simulacije modela pa prikazujejo delež zemljišč, namenjen pozidavi, ekonomskim dejavnostim, vključno s kmetijstvom, ter naravnim območjem, obseg spremembe namenske rabe rabe tal iz kmetijske v nekmetijsko ter analizo, katera zemljišča glede na proizvodno sposobnost so najbolj podvržena pozidavi v primeru vsakega posameznega mogočega scenarija. Rezultati simulacij so opredeljeni tudi prostorsko za celo občino ter na ravni posameznih krajevnih skupnosti Mestne občine Koper in lahko služijo za podporo odločanju o prihodnjem prostorskem razvoju občine.

\section{SLOVENSKI PRIMERI UVAJANJA LOKALNE TRAJNOSTNE OSKRBE S HRANO}

\section{I. Projekt 'Z lokalno oskrbo hrane do zdravja' v Pomurju}

V Pomurju se je v zadnjih petih letih izvajal projekt ' $Z$ lokalno oskrbo hrane do zdravja'. Izhodišče tega projekta je predstavljala že omenjena 'Resolucija o nacionalnem programu prehranske politike 2005-2010', ki je bila zgrajena na dokumentih 'Zdravje za vse v 21. stoletju' in 'Agendi 21'. S projektom so v Pomurju želeli zagotoviti varno hrano od 'njive do krožnika', prispevati k izboljšanju prehranskih navad otrok in mladostnikov, pa tudi celotne populacije ter vzpostaviti kratke prehranske verige z lokalno pridelano hrano. Kot lokalni trg so definirali območje, oddaljeno $60 \mathrm{~km}$ od lokalnega ponudnika. Ustrezne količine, pestrost ponudbe in primerna organiziranost ponudnikov so se pokazali kot slabosti malih ponudnikov in hkrati kot izziv projekta (Buzeti 2006, 2).

Zaradi tega so se odločili za dve obliki organiziranja oziroma povezovanja proizvajalcev: konzorcij LTO Pomurja (mreža lokalnih ponudnikov, ki povezuje lokalne pridelovalce sadja in zelenjave ter ekoloških pridelkov na osnovi konzorcijske pogodbe z definirano odgovornostjo članov in predstavnikom, ki skrbi za logistiko, trženje in promocijo) in Ekološki center SVIT (neprofitni zavod kot partnerstvo med civilno iniciativo in gospodarskim subjektom; ustanovitelji so Društvo za biodinamično kmetovanje Ajda Prekmurje, Društvo za socialno vključenost Mozaik in Mlinarstvo Kolenko; center skrbi za izobraževanje pridelovalcev in

\footnotetext{
1 PLUREL - Peri-urban Land Use Relationships - projekt 6. okvirnega programa EU, št. pogodbe 036921. Partner v projektu je tudi Biotehniška fakulteta, Oddelek za agronomijo; http://www.plurel.net.
} 
potrošnikov, promocijo in trženje). Z animacijo in usposabljanjem pripravljalcev javnih naročil na osnovnih šolah in vrtcih so želeli dvigniti njihovo znanje in raven priprave javnih razpisov tako, da bo kakovost in želja šole po zagotavljanju zdrave in kakovostne hrane na prvem mestu. V projektu se je izkazalo, da lokalni trg ne pozna dovolj lokalne ponudbe, tako v šolah kot v vrtcih in gostinskih obratih. Zarade tega so razvili še akcijo 'Spoznajmo, kaj imamo', kjer enkrat letno organizirajo ogled lokalne ponudbe v okviru strokovnih ekskurzij za predstavnike šol in vrtcev ter gostinsko-turističnega sektorja. Projekt ima tudi socialno vsebino, saj vključujejo tudi ranljive skupine, kot so dolgotrajno brezposelni in osebe s posebnimi potrebami.

\subsection{Projekt 'Lokalna trajnostna oskrba s hrano v Posavju'}

V letu 2009 je Lokalna akcijska skupina (LAS) Posavje s partnerji Center za razvoj podeželja Posavje, Zavod Vrbov Log (oz. Zavod Svibna) ter Kmečka zadruga Sevnica pripravila projekt 'Lokalna trajnostna oskrba s hrano v Posavju', ki pokriva celotno območje Posavja. S projektom želijo ugotoviti, ali na območju LAS Posavje obstajajo možnosti za samooskrbo, oziroma določiti stopnjo samooskrbe s kmetijskimi pridelki in živilskimi izdelki iz skupine žit, sadja, zelenjave in mesa v shemah kakovosti (integrirano in ekološko kmetovanje) ter možnosti za uvajanje lokalno pridelane hrane v javne ustanove (vrtci, šole, bolnišnica, domovi za starejše v Posavju).

Namen projekta je v naslednjih letih čim več v Posavju pridelane hrane (s poudarkom na integrirani in ekološki pridelavi) tudi porabiti v regiji. Priložnost vidijo v povezovanju pridelovalcev, trgovcev in potrošnikov. Na ta način bo lokalnim pridelovalcem zagotovljeno tržišče oziroma distribucija lastnih pridelkov na lokalni ravni. Lokalna trajnostna oskrba ustreza tudi pridelovalcem na sorazmerno majhnih kmetijah, saj jim zagotavlja določeno tržišče. S tem se bo okrepila tudi ekonomska moč vključenih kmetij. Projekt naj bi s tem prispeval tudi k varovanju in ohranjanju okolja ter omogočal tudi razvoj inovativnih delovnih mest na podeželju (medmrežje 4).

V projektu so že stekle analize ponudbe hrane 14 ekoloških in 11 integriranih pridelovalcev hrane (med slednjimi so se pretežno odzvali sadjarji). Identificiranih je bilo deset kmetijskih pridelkov (živilskih proizvodov), ki bi bili primerni za vključitev v lokalno trajnostno oskrbo $\mathrm{s}$ hrano v javnih ustanovah, zato je bilo v projekt analize ponudbe lokalno pridelane hrane vključenih tudi pet javnih ustanov, ki so za to izrazile interes. Potekala so preverjanja, kakšna je ponudba lokalno pridelane hrane in kakšne so možnosti za vključevanje te hrane v okolje $\mathrm{v}$ javne ustanove (v vrtce, šole, domove za starejše, bolnišnice ...). Na osnovi opravljenih analiz so bila izdelana merila in kriteriji za lokalne pridelke in živila 'od njive do krožnika' ter model uvajanja lokalno pridelane hrane $\mathrm{v}$ javne ustanove.

Dosedanje ugotovitve kažejo, da je interes velik, težave pa nastopijo pri javnih naročilih. Pri sezonsko pridelani hrani je namreč težko zagotoviti celoletno ponudbo, po drugi strani pa je pri izbiri na javnem razpisu zaenkrat edini kriterij najnižja cena ponudnika. Še vedno je tudi veliko strahu in rezerve, zato bo potrebno še veliko pogovorov in gradnje zaupanja med pridelovalci in potrošniki. V načrtu je tudi registracija blagovne znamke 'Pridelano v Posavju' (medmrežje 5). 


\section{SKLEP}

Večje podražitve hrane na svetovni ravni v zadnjem času, višje cene energentov, ki dražijo predelavo in transport ter vse opaznejše posledice podnebnih sprememb z vplivom na kmetijsko pridelavo, so resno opozorilo vsem državnim ustanovam in prebivalcem, da bo potrebno o hrani kot strateškem viru vsake države v prihodnje razmišljati drugače. Zagovorniki globalističnih razmišljanj, ki menijo, da je prek dobro organizirane trgovine mogoče prehranske pridelke in izdelke pripeljati iz kateregakoli dela sveta, dobivajo tudi bolj trezne nasprotnike v zagovornikih lokalne oskrbe.

Transporti hrane (tudi medcelinski) so v končnem seštevku predragi, saj povzročajo tudi onesnaževanje okolja in izgubljanje prehranske vrednosti živil, ki so zato tudi z vidika zdravja manj kakovostna, saj so pogosto še dodatno kemično tretirana, da vzdržijo vse prevoze. Uvoz hrano tudi podraži, povečuje odvisnost lokalnega trga od svetovnega in posledično zmanjšuje pridelavo doma, saj domači pridelovalci ne najdejo trga. Ne podpira tudi razvoja na osnovi lokalnih virov. Zavedanje o teh vplivih je vse večje ob zadnjih podražitvah hrane tudi v Sloveniji, čeprav še zdaleč ne izkoriščamo dovolj vseh možnosti lokalne samooskrbe s hrano. Če bi v ceno hrane všteli tudi okoljske stroške, v Sloveniji ne bi več prodajali npr. novozelandske čebule, saj imamo doma avtohtono in bolj zdravo čebulo s Ptujskega polja, a zaradi globalistične logike trgovskih centrov jemo uvoženo.

Korak naprej (vsaj teoretično) na tem področju je bil pri nas narejen z Resolucijo o nacionalnem programu prehranske politike, ki vključuje tri strateško pomembna področja: varnost živil, uravnoteženo in varno prehranjevanje ter zagotavljanje trajnostne oskrbe z živili, pri čemer daje prioriteto prav lokalni pridelavi in lokalni porabi.

Struktura pridelave in prireje se bo v prihodnje morala bistveno bolj kot doslej prilagajati povpraševanju potrošnikov, saj k temu pridelovalce usmerja v letu 2009 uvedena delno reformirana kmetijska politika. Zdi se, da bo prilagajanje povpraševanju edina možna pot za ohranitev in razvoj slovenskega kmetijstva. Tržne priložnosti za večjo ponudbo domačega sadja in zelenjave ostajajo še precej neizkoriščene, prav tako je skromna raznolikost ponudbe pridelkov. Pri tem postaja ključnega pomena osveščenost prebivalstva, predvsem v luči povpraševanja po svežih in kakovostnih domačih pridelkih. Domača kmetijska dejavnost bo gotovo sledila povpraševanju. Predvsem pa bi bilo v prihodnje potrebno dati več pozornosti lokalni in regionalni oskrbi s kmetijskimi pridelki, pri čemer bo potrebno izboljšati sodelovanje in organiziranost pridelovalcev ter izboljšati prodajne poti in komunikacijo med proizvajalci in lokalnimi/regionalnimi potrošniki, tako individualnimi kot različnimi ustanovami (šole, vrtci, domovi za starejše, podjetja ipd.).

Ali ima torej Slovenija možnosti za lokalno oskrbo s prehranskimi proizvodi? Odgovor je pozitiven, saj možnosti za to (vsaj do določene mere) imamo, te možnosti pa prav gotovo niso še dovolj izkoriščene. Da bi jih lahko bolje izkoristili, je potrebno več vložiti v ozaveščenost potrošnikov, v izobraževanje in usposabljanje kmetov, v raziskave na področju kmetijstva ter nove tehnologije, $\mathrm{v}$ organiziranost pridelovalcev in njihov skupni nastop na trgu, v odpravljanje birokratskih ovir (npr. v javnih razpisih). Prav tako je potrebno bolje varovati kmetijske proizvodne potenciale, ki se $\mathrm{v}$ zadnjih letih zaskrbljujoče zmanjšujejo na račun spremembe namembnosti kmetijskih zemljišč v zazidljiva, po drugi strani pa se vse večji delež 
kmetijskih površin uporablja tudi za neprehranske namene. Obširna koruzna polja se namenjajo predelavi v silažo kot surovinsko osnovo rastočim bioplinarnam. Tudi evropsko določilo o potrebnem obsegu pridelave biogoriv zmanjšuje pridelavo za prehranske namene ne le v Sloveniji, temveč tudi na globalni ravni. Evropske države zaradi te zahteve kupujejo ali najemajo zemljišča tudi v Afriki, Aziji in Braziliji, da na njih pridelujejo energetske rastline. Na ta način še dodatno povzročajo težave z zagotavljanjem hrane in lokalne oskrbe prebivalcem teh (večinoma revnih) držav.

\section{Viri in literatura}

Buzeti, T. 2006: Z lokalno oskrbo do hrane in zdravja. Novine Živimo zdravo, tematska številka: Z lokalno oskrbo hrane do zdravja 1, 3-4. Murska Sobota.

London food strategy. London Development Agency, London 2006.

Medmrežje 1: Analiza stanja ekološkega kmetijstva v Sloveniji2005-2008. http://www.zvezaekokmet.si/strani/ekolosko_kmetijstvo/analiza_stanja.htm (10.9. 2010).

Medmrežje 2: Osnutek resolucije o strateških usmeritvah razvoja slovenskega kmetijstva in živilstva. http://www.mkgp.gov.si/si/splosno/vstopna_stran/aktualne_teme/PType/98/ (20.9. 2010).

Medmrežje 3: http://www.stat.si (10. 9. 2010).

Medmrežje 4: http://www.rra-posavje.si/index.php?lg=0\&mf=4\&mc=230\&pg=439 (20. 9 . 2010).

Medmrežje 5: http://www.posavje.info/novice/81-novice/4794-pridelano-v-posavju-naj-imaprednost (20.9. 2010).

Nacionalni program prehranske politike od 2005 do 2010. Ministrstvo za zdravje Republike Slovenije. Ljubljana 2005.

Osnutek resolucije o strateških usmeritvah razvoja slovenskega kmetijstva in živilstva. Medmrežje:http://www.mkgp.gov.si/si/splosno/vstopna_stran/aktualne_teme/PType/98/ (23.9.2010).

Perpar, A., Mubareka, S., Deranja, D., Pintar, M. 2010: Projekcije prihodnje rabe tal v Mestni občini Koper na podlagi modela MOLAND (članek v recenziji).

Pintar, M., Lobnik, F., Bohanec, B. 2010: Apel proti pozidavi kmetijskih zemljišč. Medmrežje: http://www.bf.uni-lj.si/fileadmin/users/1/../izjava_za_javnost_KZem.pdf (10. 8. 2010).

Poročilo o stanju kmetijstva, živilstva in gozdarstva v letu 2008. Ministrstvo za kmetijstvo, gozdarstvo in prehrano in Kmetijski inštitut Slovenije. Ljubljana 2009.

PRP 2007-2013 (Program razvoja podeželja Republike Slovenije za obdobje 2007-2013) 2010. 4. sprememba.

Medmrežje: http://www.mkgp.gov.si/si/program_razvoja_podezelja_2007_2013/vsebina_ programa_razvoja_podezelja/predlog_4_spremembe_prp/ (22.9. 2010).

Resolucija o nacionalnem programu prehranske politike od 2005 do 2010. Uradni list RS, št. 39/2005. Medmrežje: http://www.uradni list.si/1/objava.jsp?urlid=200539\&stevilka= 1392 (15. 9. 2010). 


\section{EXISTING POTENTIAL FOR LOCAL FOOD SUPPLY IN SLOVENIA}

\section{Summary}

Food supply on a global level is becoming even more unstable because of the different reasons. One is the population growth on the planet (the forecast of the UN is that nine billion people will live on the Earth in 2050). Taking into account that living standard in China and India will increase also means that quantity of food should be almost doubled. The other reasons are: global climate changes with more frequent extreme circumstances and natural catastrophes, global organized trade chains, decreasing of agricultural land because of changed land use to built-up land and use in non-food production, abandoning of agricultural activities and consequently overgrowing of agricultural land etc.

Mentioned reasons contributed that importance of local food supply has been recognized also in Slovenia. Slovenia is net importer of agricultural products. The degree of self-sufficiency is higher for animal than for plant products. Permanent surpluses appear only for hops, poultry meat, milk and fresh apples; supply with beef and meat of sheep and goats is more or less balanced, meanwhile permanent deficit appears for sugar, vegetable oil, vegetables, cereals, fresh fruits, potatoes, pork, honey and eggs. In wine production import-export status is changing; Slovenia is net exporter of quality wine and net importer of table wine.

Around 77,000 agricultural households in Slovenia are engaged in the production but the number is decreasing in the last years. In the agricultural land use structure permanent meadows and pastures are predominant, while arable land is limited. Best agricultural land is on alluvial plains where the pressure for settlement, business and infrastructure construction is the highest.

The natural conditions for agriculture in Slovenia are not favourable. Almost $85 \%$ of national territory ( $72.5 \%$ of all agricultural land in use) belongs to less favourable areas. Farms are small (average size 6.3 ha of utilized agricultural area) and fragmented, so high productivity and good economic results of production are difficult to achieve. Agricultural production is performed on around 500,000 ha of agricultural land, but serious concern is that the amount of the best arable land is constantly decreasing. In the period 2002-2007 Slovenia lost on average 7 ha of arable land per day on account of urbanization, and in the new proposals of spatial plans prepared by Slovenian municipalities appetites for land use change from agricultural to built-up land are still high. Better protection of best agricultural land therefore is much needed. Today we have still only $880 \mathrm{~m}^{2}$ of arable land per inhabitant, but for the basic self-sufficiency we would need at least $2,000 \mathrm{~m}^{2}$.

Organic farming in Slovenia is performed on $2.7 \%$ of farms $(2,046$ farms $)$ with $4.8 \%$ $(29,836$ ha) of total agricultural land engaged in such production. Obstacles for a better local food supply are also: tradition and natural conditions for farming in Slovenia more connected with animal production, no organized producers for common appearance on market, opened European market and globally organized trade chains, weak knowledge about local supply among individual customers and organizations, modest offer of heterogeneous products and small volume of products, weak awareness about the quality of food, production of plants for 
energetic purposes on arable land, bureaucratic obstacles (i.e. the most important factor on public tenders is the price and not quality) etc.

The real potential for local food supply in Slovenia exists, however, above mentioned obstacles are decreasing these possibilities. Recognition that locally produced food is of higher quality and healthier, while local production and consumption contribute to the maintenance of the countryside and working places, to protection of the environment, to increase soil quality and biodiversity, gives an increasing importance to the local food supply. Much emphasis has been placed on local food supply in 'The resolution on national programme of food policy' and in partly reformed agricultural policy, while on a local level some local action groups have started to organize a local food supply.

(Translated by Anton Perpar and Eleonora Marendič) 